\title{
Бороздина О.С. \\ Общность как условие формирования просоциальной субъектной позиции у верующих осужденных
}

Вологодский институт права и экономики ФСИН России (Россия, Вологда)

doi 10.18411/spc-04-03-2018-04

idsp 000001:spc-04-03-2018-04

Abstract

The article is devoted to the formation of prosocial subjective position of the faithful prisoners. Building event-driven community of believers convicts is considered as a basic condition for forming the specified position.

Key words: prosocial subject position, event common-ness, convicted believers.

Одним из приоритетных направлений реформирования уголовноисполнительной системы является разработка базовых программ формирования просоциальной направленности личности осужденных, профилактики деструктивных проявлений, ресоциализации и дальнейшей интеграции в общество.

Исправление верующих осужденных имеет особое значение. Согласно Толковому словарю русского языка Ушакова, «верующий» означает «признающий существование Бога, религиозный человек». По данным исследований $89 \%$ осужденных считают для себя религиозную мораль более привлекательной, нежели светская, общественная. «Развитое в человеке религиозное чувство значительно превосходит по своему регулятивно-обеспечительному ресурсу государственное принуждение и силу общественного мнения, так как для верующих людей основанием для честной и праведной жизни в строгом соответствии с нормами и канонами является вера в то, что за этими заповедями стоит абсолютный авторитет Господа, что исключает возможность сомнений в необходимости их соблюдения и согласования с ними своих действий и поступков, так как глубоко верующий человек выстраивает линию своего поведения на основе сознательно выбранных им, а не навязанных кемлибо извне или же исполняемых вынужденно, норм. Закрепление правильных понятий о религии и своем месте в окружающем мире выполняет важную функцию расширения духовного пространства личности и горизонтов религиозного сознания и служит базой для выработки привычки правомерного поведения» [4, с. 19 - 20]. Таким образом, религиозная вера осужденного несет в себе значительный позитивный потенциал для воспитательной работы.

Для достижения эффективности воспитательной работы необходимо глубокое понимание сущности и критериев исправления осужденных. С позиции личностного подхода в педагогике исправление должно быть представлено в аспекте нравственного изменения личности осужденного и формирования на этой основе правопослушного поведения, соответствующего нравственным и правовым нормам, принятым в обществе и государстве (на уровне действующего законодательства). С нашей точки зрения, одним из основных критериев исправления осужденного выступает сформированность у него просоциальной субъектной позиции как интегрального личностного новообразования. Под просоциальной субъектной позицией мы понимаем внутреннюю волевую позицию человека, основанную на системе ценностных отношений к миру, другим людям, себе самому, позволяющую ему осознанно, ответственно и свободно строить свою жизнь, совершая просоциальные поступки и жизненные выборы. В свою очередь, просоциальное поведение - это поведение индивида, которое ориентировано на благо социальных групп и является 
противоположным антисоциальному поведению, когда человек пытается вредить другим или совершает агрессивные поступки [1, с. 94].

Становление осужденного просоциальным субъектом соответствует требованиям времени, так как в значительной мере готовит его к реинтеграции в современное общество. При этом субъект понимается как носитель предметнопрактической активности и познания, осуществляющий изменение в других людях и в себе самом. «Субъектность - способность человека быть стратегом своей деятельности, ставить и корректировать цели, осознавать мотивы, самостоятельно выстраивать действия и оценивать их соответствие задуманному, выстраивать планы жизни» [3, с. 144]. Субъектность человека проявляется в его жизнедеятельности, общении, самопознании. Субъект деятельности характеризуется проявлением инициативы и самостоятельности, способностью принимать и реализовывать решения, оценивать последствия своего поведения, самоизменяться, самосовершенствоваться. Субъектная позиция по отношению к собственной жизни лежит в основе личности и составляет суть личностного бытия человека. Иначе говоря, личность не может состояться без развития субъектной позиции. Субъектный опыт - это опыт такой деятельности, при выполнении которой индивид занимает субъектную позицию, т.е. самостоятельно определяет цель деятельности, ее средства, план осуществления, анализ и коррекцию результатов (Л.М.Кларина).

Главным в субъектной позиции является отношение к самому человеку, которое формируется в борьбе двух разнонаправленных векторов, один из которых ведет к пониманию и реализации человека как самоценности, а другой, противостоящий ему,к пониманию и реализации человека как средства. Разрешение конфликта, противоречия в пользу первого отношения ведет к утверждению сущности человека, тогда как в случае превалирования второго рода отношений человек выступает в меновой, вещной, т. е. в конечном счете нечеловеческой форме своего существования [2]. Поведение, ориентированное на благо общества и помощь людям определяется как просоциальное поведение. Модель просоциального поведения включает в себя:

а) позитивные представления личности о себе, связанные со способностями к солидарности и сочувствию, а также определяющие отношение к другим, что отражается в способностях к эмпатии, в сотрудничестве и взаимопомощи, в умении разрешать конфликтные и трудные ситуации;

б) систему жизненных ценностей, которые определяют стратегии взаимодействия с миром;

в) способность личности реализовывать себя на пути альтруистической, общественно значимой деятельности [5]. компоненты:

Структуру просоциальной субъектной позиции составляют следующие

- мотивационно-ценностный (смыслы и направленность мотивов жизнедеятельности, способность к целеполаганию, стремление к самореализации);

- волевой (саморегуляция жизнедеятельности, способность к самостоятельному преодолению жизненных проблем в реализации жизненных целей);

- деятельностный (активность, инициативность);

- рефлексивный (адекватность самооценки и оценки окружающей действительности).

Таким образом, сформированность у осужденных просоциальной субъектной позиции выступает основным критерием их исправления. Поэтому особое значение приобретает выявление условий формирования у осужденных указанной позиции. 
Условия формирования у осужденных просоциальной субъектной позиции связаны с психологическими механизмами становления и развития субъективности. Отвечая на вопрос, каковы механизмы становления и развития субъективности в пределах индивидуальной жизни, В.И. Слободчиков отмечает, что источником (объектом) ее развития не может быть индивид. Объектом (источником, ситуацией) развития субъективной реальности ( $\mathrm{a}$, следовательно, и субъектной позиции) в онтогенезе является со-бытийная общность [6, с.169].

Для общности характерно принятие людьми друг друга. Исходная её норма устойчивая духовная связь между её участниками, обеспечивающая взаимопонимание между людьми, которая возникает при постоянном общении, диалоге, взаимном доверии и сопереживании. Нормы, цели, ценности, смыслы привносят в общность сами люди, делая её подлинно со-бытийной. Со-бытийная общность - это живое единство, сплетение и взаимосвязь двух и более жизней [7, с.25].

В основе жизнедеятельности событийной общности лежит совместная, личностно значимая для каждого из участников просоциальная деятельность. В рамках достижения общих просоциальных целей у участников общности и вырабатывается просоциальная субъектная позиция.

Исходя из вышеизложенного, центральным условием формирования у верующих осужденных просоциальной субъектной позиции является включение их в событийную общность. Для верующих осужденных основу событийной общности могут составить такие духовные объединения, как религиозные группы, которые дефакто образовываются и функционируют в местах лишения свободы в течение длительного времени для поддержания осужденными-единоверцами своей религиозной идентичности, совместного духовного развития и коллективного отправления религиозных культов. При этом основная идея - организация просоциальной общности верующих осужденных на базе значимой для них совместной деятельности. Согласно российскому законодательству о свободе совести и вероисповедания право на создание религиозных групп не подлежит каким-либо изъятиям и ограничениям, а религиозные группы как разновидности религиозных объединений обладают правомочиями совершать богослужения, другие религиозные обряды и церемонии, а также осуществлять религиозное обучение и воспитание своих последователей $[4, \mathrm{c.21}]$. Для достижения цели формирования у верующих осужденных просоциальной субъектной позиции необходимо комплексно использовать все средства исправления осужденного, предусмотренные ст. 9 УИК РФ [8]. Важнейшими из основных средств исправления осужденных являются установленный порядок исполнения и отбывания наказания (режим) и труд. Изначально необходимо выделить осужденным время для оборудования своими силами молельной комнаты, изготовления предметов для отправления культа, постройки храма. В настоящее время в исправительных колониях запрещено принуждать осужденных к труду, но законодатель устанавливает возможность привлечения осужденных к общественно-полезному труду, продолжительность которого составляет 2 часа в неделю. Предоставляется также право увеличения продолжительности работы по письменному заявлению осужденных (ст. 106 УИК РФ) [8]. При этом важно, чтобы в процессе оборудования и поддержания в порядке мест отправления религиозного культа, совместного участия в религиозных обрядах постепенно складывалась событийная общность верующих осужденных, реализующая в совместной деятельности просоциальные цели.

Большое влияние на формирование просоциальной субъектной позицииверующих осужденных может оказать общественность, и, прежде всего, служители культа различных религиозных конфессий. Так, Соглашение о сотрудничестве между Федеральной службой исполнения наказаний России и Русской 
Православной Церковью, заключенное 22 февраля 2011 года, предусматривает окормление священниками верующих осужденных в исправительных колониях совершение служб, обрядов, таинств, религиозное просвещение осужденных.

Таким образом, центральным условием формирования у верующих осужденных просоциальной субъектной позиции является их участие в событийной общности, создаваемой на основе значимой для всех участников просоциальной деятельности.

$$
* * *
$$

1. Бороздина О.С. Общность как условие формирования просоциальной субъектной позиции у несовершеннолетних осужденных // Уголовно-исполнительная система на современном этапе: взаимодействие науки и прак-тики: материалы Международной научно-практической межведомственной конференции (16 - 17 июня 2016 г.) / под общ. ред. А.А. Вотинова. - Самара: Самарский юридический институт ФСИН России, 2016. - 758 с. - С. 92 - 96.

2. Братусь Б.С. Аномалии личности.- М.: Мысль, 1988.

3. Коджаспирова Г.М., Коджаспиров А.Ю. Педагогический словарь: Для студ высш и сред пед учеб заведений. - М.: Издательский центр «Акаде-мия», 2000.

4. Лещенко В. Г. Религиозное воздействие на осужденных к лишению свободы в Российской Федерации. Автореф. дисс.... канд. юридич. наук. - Екатеринбург, 2012. - 28 с.

5. Мазур Ю. О. Социально-психологический тренинг личностного роста как средство развития просоциального поведения. - Автореф. дис. канд. пси-хол. наук. - Ярославль, - 2008.

6. Слободчиков В.И., Исаев Е.И. Основы психологической антрополо-гии. Психология развития человека: Развитие субъективной реальности в он-тогенезе: Учебное пособие для вузов. — М.: Школьная Пресса, 2000.

7. Слободчиков В.И. Педагогика Антона Семёновича Макаренко - соци-ально-педагогическое открытие XX века // Народное образование. 2006. № 6. С. 20 - 28.

8. Уголовно-исполнительный кодекс Российской Федерации от 08.01.1997 N 1-Ф3 (ред. от 24.11.2014, с изм. от 01.12.2014) // Собрание законодательства РФ. 13.01.1997. N 2. ст. 198.

\section{Волокитин А.В., Савввина Н.П. \\ Развитие физических качеств у студентов на основе использования единоборств}

Липецкий государственный технический университет (Россия, Липеик)

doi 10.18411/spc-04-03-2018-05

idsp 000001:spc-04-03-2018-05

\section{Abstract}

This article offers common thoughts about a promotion of healthy lifestyle using single combats. Also there is revealing main results of research about the influence of judo for students in their physical study time.

Keywords: physical education, single combats, physical abilities, psychological abilities, research.

В данной статье предлагается обзор основных суждений о пропаганде здорового образа жизни посредством единоборств, и выявление основных результатов исследования, посвященному влиянию занятиями дзюдо на студентов в процессе учебных занятий.

В настоящее время система физического воспитания студентов не отвечает современным требованиям и является малоэффективной. Следствием этого является снижение уровня физической подготовленности, функционального состояния, работоспособности студенческой молодежи. Традиционные формы, средства и методы организации и проведения занятий по физической культуре не решают проблем повышения уровня физического состояния. Наряду с этим среди молодежи все более популярными становятся занятия единоборствами. Целью единоборств как вида спортивной деятельности является всесторонняя подготовка человека, в том числе и к критическим жизненным ситуациям. 